\title{
ATORVASTATIN AMELIORATES CISPLATIN INDUCED OXIDATIVE STRESS IN EHRLICH ASCITES SOLID TUMOR-BEARING MICE: A PROSPECTIVE CASE CONTROL STUDY
}

\author{
By \\ Ola Sayed Mohamed Ali*, Noha Abdel-Rahman Eldesoky*, \\ Ahmad Muhammad Salahuddin**, and Nehal Mohamed Abdel-Aziz Eisa* \\ *Biochemistry Department, Faculty of Pharmacy (Girls), Al-Azhar University \\ ** Biochemistry Department, Faculty of Pharmacy, Damnhour University
}

\begin{abstract}
Background: A relationship was observed between cholesterol and the development of many cancer types. However, the efficacy of the addition of hypolipidimic medications to cancer treatment regimen is unclear. Objective: To study the possible effects of atorvastatin on Ehrlich solid tumor bearing mice treated with cisplatin and to explore atorvastatin effects on inflammation and oxidative stress. Materials and methods: Sixty female Swiss albino mice were divided into five equal groups: Negative control, positive control, cisplatin treated, atorvastatin-treated and combination of cisplatin-and atorvastatin-treated group. Tumor volume, total antioxidant capacity, catalase, malondialdehyde, C-reactive protein and angiogenin were determined. Results: Markers of oxidative stress were the worest in cisplatin-treated group and the best in combination-treated group as there was significant increase in serum catalase and a relative increase in serum total antioxidant capacity (TAC) than cisplatin treated group. Moreover, serum malondialdehyde (MDA) showed relative decrease in combination-treated group than cisplatin-treated group.
\end{abstract}

Conclusion: The use of atorvastatin/cisplatin combination therapy increased antioxidant enzymes and decreased cisplatin induced oxidative stress pointing at the antioxidant effect of atorvastatin as a possible mechanism for its anticancer activity.

Keywords: Breast cancer, Ehrlich Ascites Carcinoma, Cisplatin, Atorvastatin, Oxidative Stress, Angiogenin.

\section{INTRODUCTION}

Breast cancer is a malignant tumor occurs in breast cells. Incidence of breast cancer is increasing worldwide, despite the huge improvement in breast cancer prognosis and survival (Torre et al., 2017). In Egypt, the incidence of breast cancer between women reached almost $18.9 \%$ of all diagnosed cancer cases (Ashraf et al., 2013).
Solid Ehrlich ascites carcinoma is an undifferentiated carcinoma, that has the high transplantable capacity, quick multiplication, no-relapse, short life expectancy, $100 \%$ malignancy and does not have tumor specific transplantation antigen. It resembels human tumors and is regularly utilized as a model of solid tumor experiments (Ozaslan et al., 2011). 


\section{OLA SAYED MOHAMED ALI $e t$ al.}

Cisplatin is one of the early successes of chemotherapy for solid tumors. It is often used as a part in combinationtreatment with other anticancer agents (Apps et al., 2015). It has a toxic profile including nephrotoxicity, gastrointestinal toxicity, neurotoxicity, ototoxicity and oxidative stress (Salman et al., 2014).

Many studies have discussed the actions of statins, besides their usage in cardiovascular and coronary heart diseases as cholesterol-lowering agents. They have found that statins exhibit a vast range of pleiotropic effects that may significantly contribute to the treatment of other diseases, such as inflammatory and pathologic conditions and even tumors. A potent inhibition of the endogenous mevalonate pathway is the commonly known pharmacological activity of statins, which leads directly to decrease in the biosynthesis of cholesterol and numerous isoprenoids such as geranylgeranyl pyrophosphate (GGPP1) and farnesyl pyrophosphate (FPP) (Oesterle et al., 2017).

Statins bind to mammalian HMG-CoA reductase at nanomolar concentrations, leading to an effective displacement of the natural substrate HMGCoA (Kabel et al., 2013).

The aim of this study was to study the possible effects of atorvastatin on Ehrlich solid tumor bearing mice-treated with cisplatin, and to explore atorvastatin effects on inflammation and oxidative stress.

\section{MATERIALS AND METHODS}

\section{Animals:}

In the present study, we used adult female Swiss albino mice were obtained from the animal house of the National Cancer Institute (NCI), weighing 18 to 20 g. Mice were fed standard pellet chow (ElNasr Chemical Company, Cairo, Egypt) and were allowed free access to water. For acclimation, animals were housed in normal temperature and normal dark/light cycle for one week before the experiment.

All the experiments were performed in accordance with institutional guidelines for ethical care of animals. The study protocol was approved by research ethics committee, Faculty of Pharmacy, AlAzhar University, Cairo, Egypt.

This study included 60 animals divided equally into the following groups:

- Group (1): Normal mice received vehicle only and served as a negative control group.

- Group (2): Ehrlich solid tumor bearing mice that received vehicle and served as a positive group.

- Group (3): Ehrlich solid tumor (EAC) bearing mice that received a single intraperitoneal dose of cisplatin $(7.5 \mathrm{mg} / \mathrm{kg})$ on the $12^{\text {th }}$ day of EAC cells inoculation.

- Group (4): Ehrlich solid tumor bearing mice that received an intraperitoneal dose of atorvastatin $(20 \mathrm{mg} / \mathrm{kg})$ on alternate days for 3 weeks after EAC cells inoculation.

- Group (5): Ehrlich solid tumor bearing mice that received a combination of cisplatin (a single intraperitoneal dose $(7.5 \mathrm{mg} / \mathrm{kg})$ on the $12^{\text {th }}$ day of EAC cells inoculation) and atorvastatin $(20 \mathrm{mg} / \mathrm{kg})$ on alternate days for 3 weeks after EAC cells inoculation. 
All mice on all groups (except negative control group) were exposed to the following:

Cell line: A line of Ehrlich Ascites Carcinoma (EAC) cells was used. The parent line was supplied through the courtesy of Dr. C. Benckhujsen, Netherlands Cancer Institute, Amsterdam, Netherlands. It was used for in vivo experiments, where solid tumors were induced in mice by subcutaneous inoculation of $0.1 \mathrm{ml}$ of EAC cells containing $5 \times 10^{5}$ viable tumor cells into the right thigh of the hind limb of mice. A palpable solid tumor mass (about 100 $\mathrm{mm}^{3}$ ) developed within 12 days (Osman et al., 1993). On day 22 after S.C. inoculation of EAC cells, blood was withdrawn from retro-orbital artery into vacuum tubes, and then serum was separated and stored at -20 ? for determination of serological markers. Animals were sacrificed; tumor tissues were removed, washed with normal saline and fixed in $10 \%$ formalin for histopathological examinations. Tumor dimensions were measured using Vernier caliper, then tumor volume was calculated by the modified ellipsoidal formula (Jia et al., 2005) $\{$ Tumor Volume $=$ length $\times$ width $\left.^{2} \times 0.52\right\}$.

Autopsy samples were taken from mice tumor tissues in different groups and fixed in $10 \%$ formal saline for twenty four hours. Washing was done using sterilized water, then serial dilutions of alcohol (methyl, ethyl and absolute ethyl) were used for dehydration. Specimens were cleared in xylene and embedded in paraffin at 56 degree in hot air oven for twenty four hours. Paraffin bees wax tissue blocks were prepared for sectioning at 4 microns thickness by slidge microtome. The obtained tissue sections were collected on glass slides, deparaffinized, and stained by hematoxylin and eosin stains for examination through the light electric microscope (Banchroft et al., 2012).

Serum laboratory investigations included malondialdehyde, total antioxidant capacity and catalase measured by spectrophotometric techniques (Ohkawa et al., 1979; Fossati et al., 1980 and Koracevic, 2001). C reactive protein and angiogenin were measured by ELISA (Patterson \& Higginbotham, 1965 and $\mathrm{Hu} \&$ Riordan, 1993). All were done according to the manufacturer's instructions.

Cisplatin was obtained as Cisplatine ${ }^{\circledR}$ (Mylan, USA). It was administered by intraperitoneal injection in a dose of 7.5 $\mathrm{mg} / \mathrm{kg}$ body weight. Atorvastatin was obtained as LIPITOR®, (Pfizer, Egypt). It was dissolved in $10 \%$ ethanol solution at a concentration of $2 \mathrm{mg} / \mathrm{ml}$ and administered by intraperitoneal injection in a dose of 20 $\mathrm{mg} / \mathrm{kg}$ body weight (Abd-El- Rahman and Abd-El-Motelb, 2011).

Statistical methods: IBM SPSS statistics (V. 24.0, IBM Corp., USA, 2016) was used for data analysis. Data were expressed as Mean \pm SE for quantitative parametric measures. Comparison between the groups for parametric data was done using Analysis of Variance (ANOVA) followed by Post-hoc. The 
probability of error at 0.05 was considered significant.

\section{RESULTS}

Effect of Atorvastatin on tumor volume: Intraperitoneal administration of atorvastatin to mice resulted in significant decrease in tumor volume compared to positive control group. The tumor volume relatively decreased in combination group that received cisplatin/ atorvastatin when compared with cisplatin group (Table 1).

Table (1): Mean \pm SE of tumor volume $\left(\mathrm{mm}^{3}\right)$ in all studied groups.

\begin{tabular}{|c|c|c|c|c|}
\hline Groups & $\begin{array}{c}\text { Positive } \\
\text { control group } \\
(\mathbf{N o = 1 2})\end{array}$ & $\begin{array}{c}\text { Cisplatin-treated } \\
\text { group } \\
\mathbf{( N o = 1 2 )}\end{array}$ & $\begin{array}{c}\text { Atorvastatin- treated } \\
\text { group } \\
\text { volume }\left(\mathbf{m m}^{\mathbf{3}}\right)\end{array}$ & $\begin{array}{c}\text { Combination- treated } \\
\text { group } \\
\mathbf{( N o = 1 2})\end{array}$ \\
\hline Range & $0.04-0.09$ & $0.003-0.04$ & $0.01-0.04$ & $0.005-0.03$ \\
Mean \pm SE & $0.07 \pm 0.005$ & $0.02 \pm 0.003^{\mathrm{b}}$ & $0.02 \pm 0.003^{\mathrm{b}}$ & $0.01 \pm 0.002^{\mathrm{bd}}$ \\
\hline
\end{tabular}

${ }^{\mathrm{b}}$ Significant from +ve control group.

d significant from atorvastatin-treated group.

Effect of Atorvastatin on oxidative stress: Positive control group showed significant decrease in serum catalase and serum TAC with significant increase in serum MDA compared to the negative control group. Markers of oxidative stress were the worest in cisplatin-treated group. MDA showed highly significant increase in cisplatin group than all other groups even positive control group. Serum catalase and serum TAC were the lowest in cisplatin-treated group when compared with other treated groups.

Intraperitoneal administration of atorvastatin to mice resulted in significant increase in serum catalase and serum TAC with relative decrease in serum MDA compared to positive control group.

Regarding combination-treated group, there was a significant increase in serum catalase than cisplatin-treated group and a relative increase in serum TAC than cisplatin- treated group. Moreover, serum MDA showed relative decrease in combination-treated group than cisplatintreated group (Table 2). 
ATORVASTATIN AMELIORATES CISPLATIN INDUCED OXIDATIVE... 101

Table (2): Mean \pm SE of oxidative stress markers in all studied groups.

\begin{tabular}{|c|c|c|c|c|c|}
\hline Groups & $\begin{array}{c}\text { Negative } \\
\text { control group } \\
(\mathrm{No}=12)\end{array}$ & $\begin{array}{c}\text { Positive } \\
\text { control group } \\
(\mathrm{No}=12)\end{array}$ & $\begin{array}{l}\text { Cisplatin- } \\
\text { treated group } \\
(\mathrm{No}=12)\end{array}$ & $\begin{array}{l}\text { Atorvastatin- } \\
\text { treated group } \\
(\mathrm{No}=12)\end{array}$ & $\begin{array}{c}\text { Combination- } \\
\text { treated group } \\
(\mathrm{No}=12)\end{array}$ \\
\hline $\begin{array}{c}\text { Serum MDA }(\mathrm{mg} / \mathrm{dL}) \\
\text { Range }\end{array}$ & $10.0-16.8$ & $14.5-21.1$ & $24.2-28.2$ & $15.3-19.7$ & $19.7-27.1$ \\
\hline Mean \pm SE & $13.7 \pm 0.6$ & $18.3 \pm 0.6^{\mathrm{a}}$ & $25.9 \pm 0.4^{\mathrm{a} b}$ & $17.5 \pm 0.4^{\mathrm{c}}$ & $22.9 \pm 0.8 \mathrm{abd}$ \\
\hline $\begin{array}{c}\text { Serum TAC }(m g / d L) \\
\text { Range }\end{array}$ & 3.4- 4.9 & $0.9-2.6$ & $2.1-3.2$ & $2.2-3.5$ & $3.0-3.3$ \\
\hline Mean $\pm \mathrm{SE}$ & $4.1 \pm 0.1$ & $2.1 \pm 0.2^{\mathrm{a}}$ & $2.5 \pm 0.1^{\mathrm{a}}$ & $3.2 \pm 0.06^{\mathrm{ab}}$ & $3.2 \pm 0.03^{\mathrm{ab}}$ \\
\hline $\begin{array}{c}\text { Serum Catalase (mg/dL) } \\
\text { Range }\end{array}$ & 506.6- 631.6 & $241.3-282.0$ & 286.6- 395.7 & 445.4- 530.3 & $342.1-654.6$ \\
\hline Mean \pm SE & $557.6 \pm 10.9$ & $261.5 \pm 3.9^{\mathrm{a}}$ & $338.3 \pm 10.2^{\mathrm{a}}$ & $479.7 \pm 8.5^{\mathrm{bc}}$ & $461.7 \pm 32.9^{\mathrm{bc}}$ \\
\hline
\end{tabular}

${ }^{\text {a }}$ Significant from negative control group .

${ }^{\mathrm{b}}$ Significant from positive control group .

${ }^{c}$ Significant from cisplatin-treated group .

d: significant from atorvastatin-treated group .

Effect of Atorvastatin on serum CRP: All treated groups showed significant decrease in serum CRP compared to positive control group. When comparing the three treated groups together, combination-treated group showed the lowest value (Table 3).

Table (3): Mean \pm SE of serum CRP (mg/dL) in all studied groups.

\begin{tabular}{|c|c|c|c|c|c|}
\hline $\begin{array}{c}\text { Groups } \\
\text { Serum CRP }\end{array}$ & $\begin{array}{c}\text { Negative } \\
\text { control group } \\
(\mathbf{N o = 1 2})\end{array}$ & $\begin{array}{c}\text { Positive } \\
\text { control group } \\
(\mathbf{N o = 1 2})\end{array}$ & $\begin{array}{c}\text { Cisplatin- } \\
\text { treated group } \\
(\mathbf{N o = 1 2})\end{array}$ & $\begin{array}{c}\text { Atorvastatin- } \\
\text { treated group } \\
(\mathbf{N o = 1 2})\end{array}$ & $\begin{array}{c}\text { Combination- } \\
\text { treated group } \\
(\mathbf{N o = 1 2})\end{array}$ \\
\hline Range & $3.000-8.000$ & $7.500-13.00$ & $5.900-9.00$ & $6.000-9.500$ & $5.500-9.00$ \\
Mean \pm SE & $6.275 \pm 0.4859$ & $10.52 \pm 0.6084^{\mathrm{a}}$ & $7.583 \pm 0.3183^{\mathrm{b}}$ & $7.767 \pm 0.3016^{\mathrm{b}}$ & $7.000 \pm 0.2319^{\mathrm{bd}}$ \\
\hline
\end{tabular}

${ }^{a}$ Significant from negative control group.

${ }^{\mathrm{b}}$ Significant from positive control group .

${ }^{\mathrm{d}}$ significant from atorvastatin-treated group .

Effect of atorvastatin on serum angiogenin: All treated groups showed significant decrease in serum angiogenin compared to positive control group. When comparing the three treated groups together, combination-treated group showed the lowest value (Table 4). 
Table (4): Mean \pm SE of serum angiogenin $(\mathrm{mg} / \mathrm{dL})$ of studied groups.

\begin{tabular}{|c|c|c|c|c|c|}
\hline $\begin{array}{l}\text { Serum } \\
\text { angiogenin (mg/dL) }\end{array}$ & $\begin{array}{c}\text { Negative } \\
\text { control group } \\
\mathbf{( N o = 1 2 )}\end{array}$ & $\begin{array}{c}\text { Positive control } \\
\text { group } \\
\mathbf{( N o = 1 2 )}\end{array}$ & $\begin{array}{c}\text { Cisplatin- } \\
\text { treated group } \\
(\mathbf{N o = 1 2})\end{array}$ & $\begin{array}{c}\text { Atorvastatin- } \\
\text { treated group } \\
(\mathbf{N o = 1 2})\end{array}$ & $\begin{array}{c}\text { Combination- } \\
\text { treated group } \\
(\mathbf{N o = 1 2})\end{array}$ \\
\hline Range & $75.00-200.0$ & $300.0-625.0$ & $140.0-215.0$ & $175.0-225.0$ & $150.0-220.0$ \\
Mean $\pm \mathbf{S E}$ & $117.1 \pm 12.89$ & $387.5 \pm 33.5^{\mathrm{a}}$ & $177.5 \pm 7.918^{\mathrm{b}}$ & $200.0 \pm 4.807^{\mathrm{b}}$ & $176.3 \pm 6.829^{\mathrm{b}}$ \\
\hline
\end{tabular}

${ }^{a}$ Significant from negative control group .

${ }^{\mathrm{b}}$ Significant from positive control group .

\section{Histopathological findings}

Ehrlich tumor cells appeared intact and had criteria of anaplasia as hyperchromatic nuclei with few mitosis as well as polarity and pleomorphism in both subcutaneous tissue and between the muscle bundles (Fig.1- IPx 200).

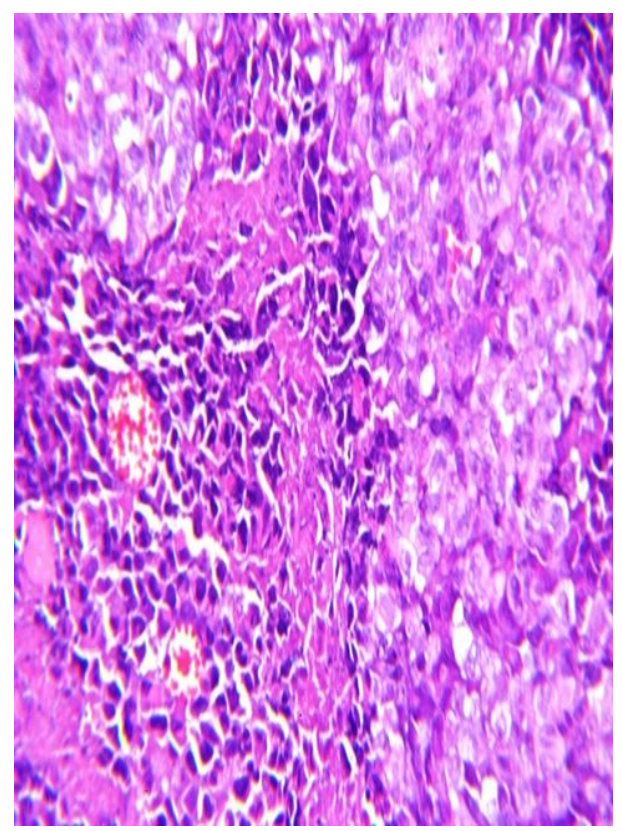

Figure (1): Positive control group

Most of the tumor cells showed apoptosis and necrosis (Fig.2- IPx100).

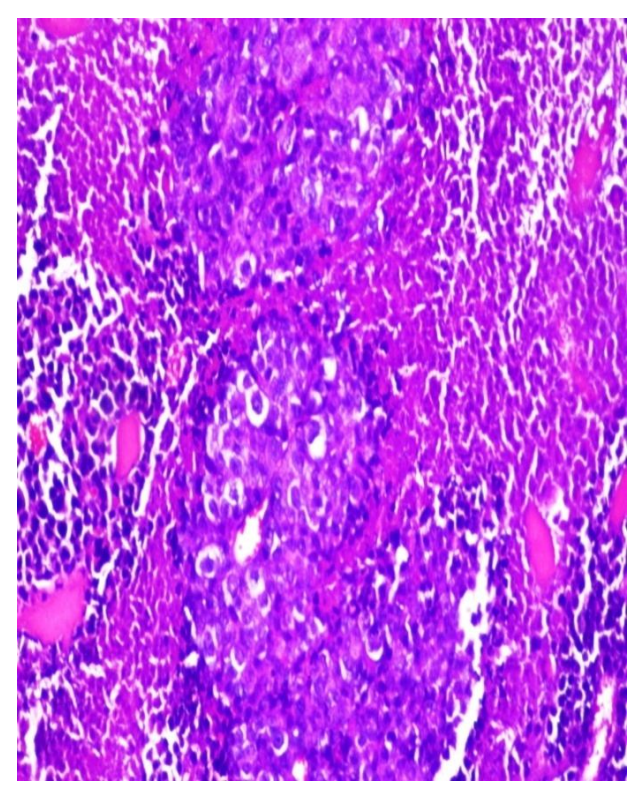

Figure (2): Cisplatin-treated group.

There was necrosis in few number of the tumor cells all over the area of tumor at the subcutaneous tissue as well as between the hyalinized muscle bundles (Fig.3- IPx 200). 


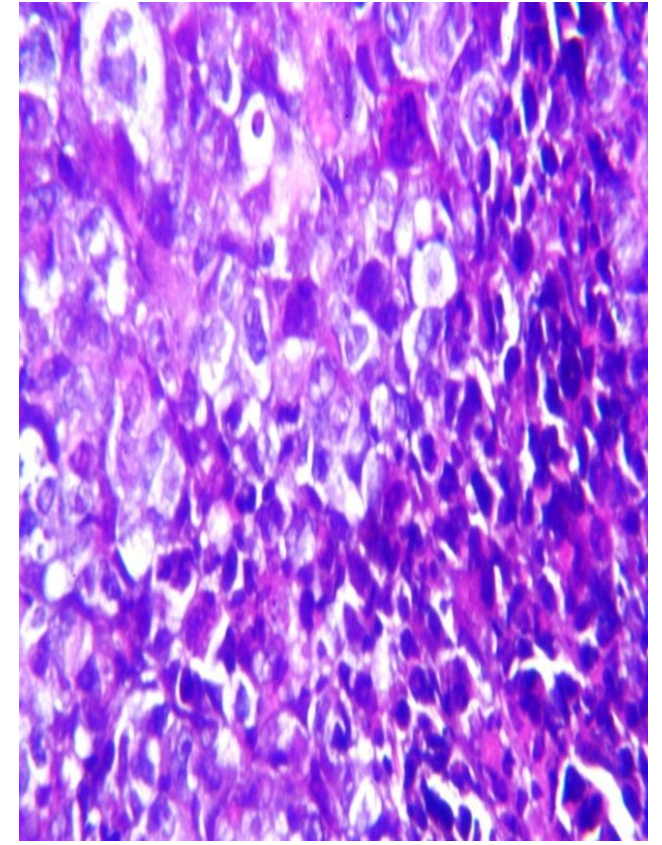

Fig. (3): Atorvastatin-treated group.

The tumor cells showed apoptosis and necrosis in most of them (Fig.4- IPx100).

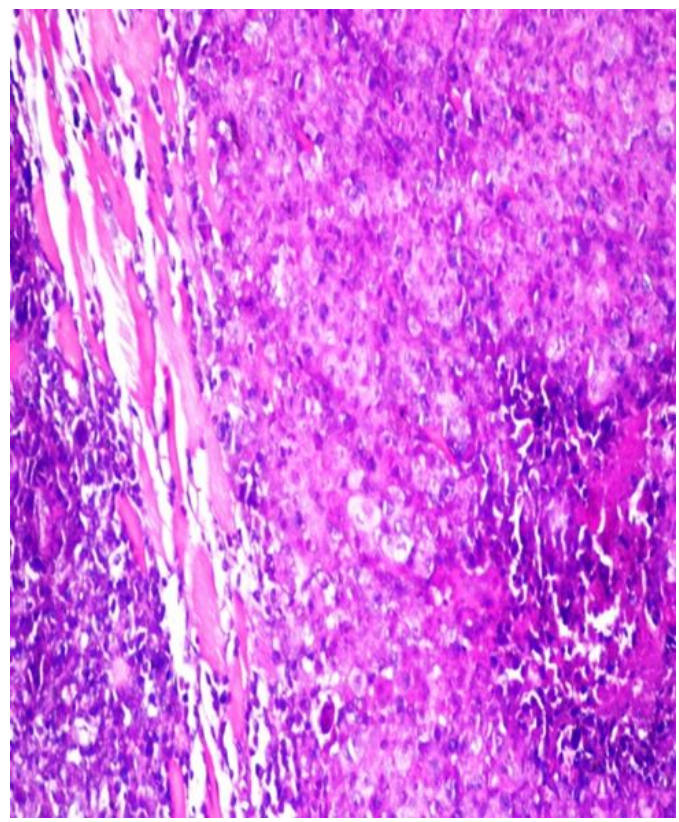

Fig. (4): Combination-treated group.

\section{DISCUSSION}

Breast cancer is the most frequently diagnosed cancer among women and the most cancer related deaths around the world (Siegel et al., 2016).
Transplantable models of cancer have the advantage of low cost, easy reproducibility and accessibility (Gaballah et al., 2017). Ehrlich ascites carcinoma resembles human tumors. So, they are frequently used in tumor studies. It is the most sensitive to chemotherapy due to the fact that it is undifferentiated and has a rapid growth rate (Ozaslan et al., 2011).

The present study was performed to estimate the effect of atorvastatin on Ehrlich solid tumor bearing mice as a combination treatment with cisplatin or as the sole treatment regimen, trying to find logic explanations and mechanisms of its action on tumor tissues also trying to explore whether the addition of atorvastatin to cisplatin in the treatment regimen of breast cancer is of value.

Statins, among the most commonly recommended drugs around the world, are cholesterol-lowering agents act by inhibition of the endogenous mevalonate pathway leading to reduction in the biosynthesis of cholesterol and isoprenoids (Oesterle et al., 2017). Moreover, statins may act as direct inhibitors to Pglycoprotein expression (Goard et al., 2010), that was proved to be responsible for resistance of tumors to chemotherapeutic agents (Xu et al., 2010).

In the present work, tumor volume decreased significantly in atorvastatintreated group and combination-treated group than positive control group. Upon histopathological examination tumor cells showed apoptosis and necrosis in most cells of combination group compared with cisplatin-treated group. These results agreed with Huang et al. (2010) who reported that atorvastatin induced apoptosis and slows tumor growth in 
mice. Pisanti et al. (2014) reported that there may be synergistic anticancer effects of statins with chemotherapeutic drugs due to induction of apoptosis such as cisplatin with cetuximab showing antiproliferative effects in K-Ras mutant cells. Also, Hindler et al. (2006) stated that there might be synergistic interactions between statins and chemotherapeutic agents such as cisplatin, methotrexate and doxorubicin.

In the current study, MDA levels significantly increased in cisplatin-treated group than positive control group reflecting cisplatin oxidative stress side effect. In combination- treated group, there was a relative reduction in MDA levels when compared with cisplatintreated group. Moreover, serum catalase increased significantly in atorvastatin and combination-treated groups when compared with cisplatin-treated group.

In agreement with our results, Boorla et al. (2014) showed that treatment of experimental animals with cisplatin and atorvastatin significantly decreased the level of MDA compared to that received cisplatin alone.

Interestingly, there was a reduction in CRP and angiogenin levels in atorvastatin- treated group almost similar to that occurred in cisplatin-treated group. Also, synergistic reductions in their levels were observed upon using combination of cisplatin and atorvastatin compared to cisplatin only although these reductions were not significant that may be attributed to small sample size or the doses of drugs used in our experiment.

Our results were in harmony with Ghaisas et al. (2010) who found that atorvastatin can improve the antioxidant status and had anti-inflammatory effects which may contribute to its antitumor effect.

CRP and angiogenin results support the idea that atorvastatin has anticancerous effect by itself, because CRP has been always used as a sensitive diagnostic/ prognostic marker both for tumor progression and responsiveness to chemotherapy in solid tumors (El-Mesery et al., 2009). Also, angiogenin has been detected in almost all types of solid tumors, playing a major role in tumor angiogenesis and its expression was found to be up- regulated in many types of cancers ( $\mathrm{Li}$ and $\mathrm{Hu}, 2012$ ).

Gazzerro et al. (2012) discussed the pleiotropic effects of statins, suggesting a potential use of these compounds beyond their lipid-lowering properties in several acute and chronic diseases mediated by both direct (via modulation of the immune-response), and indirect (via inhibition of platelet functions) mechanisms.

Also, Yang et al. (2012) stated that statins may act as chemoprotective agents against various types of cancers. Statins are potent inhibitors of HMG-CoA reductase, an enzyme responsible for the conversion of HMG-CoA to mevalonate. This action reduces synthesis of nonsterol products which are essential for the isoprenylation of intra- cellular second messenger mitogenic signaling proteins like Ras (Wali et al., 2009). Another mechanism for atorvastatin possible effect on tumor suppression was explained by Goard et al. (2010) who stated that statins may act as direct inhibitors to Pglycoprotein expression. P-glycoprotein expression was proved to be responsible 
for resistance of tumors to chemotherapeutic agents (Xu et al., 2010).

\section{CONCLUSION}

The addition of atorvastatin to cisplatin anticancer treatment regimen ameliorates cisplatin induced oxidative stress, and had some sort of synergistic anticancer effect against Ehrlich solid tumors in mice.

\section{ACKNOWLEDGMENTS}

Special thanks to Biochemistry Department, Faculty of Pharmacy (Girls), Al-Azhar University, for their sincere efforts in this work. We also feel deep gratitude towards animal house team and histopathology team in National Cancer Institute for their great help.

\section{REFERENCES}

1. Abdel Rahman, $M \mathbf{N}$ and Abd el motelb $A$. (2011): Study of atorvastatin in experimental allergic air way inflammation in mice. Int. Immunopharmacol., 11: 1090-1094.

2. Abo Gad allah, Ashraf A. EL- Bindary, Hatem A. EL-Mezayen, Hossam D, Mohammed A. Eissa and Raida S. Yahya. (2013): Antioxidants status in breast cancer patients under therapy. American Journal of Research Communication, 1(7): 152-163.

3. Apps M G, Choi E H Y and Wheate N J. (2015): The state-of-play and future of platinum drugs. Endocrine-related Cancer, 22(4): 219-233.

4. Banchroft JD, Stevens A and Turner DR. (2012): Theory and practice of histologic techniques. 7th ed.,pbl. New York/London/San Francisco/Tokyo: Churchil Livingstone, pp. 69. 93.

5. Boorla SK, Panchagiri S, Shastrala KK, Bonagiri $R$ and Vangala $M$. (2014): Evaluation of role of atorvastatin in cisplatin induced nephrotoxicity in wistar rats. Global Journal of Pharmacology, 8 (2): 279-283.

6. El-Mesery M E, Al-Gayyar MM, Salem H A, Darweish M M and El-Mowafy A M. (2009):
Chemopreventive and renal protective effects for docosahexaenoic acid (DHA): implications of CRP and lipid peroxides. Cell Division, 4(1): $1-2$.

7. Fossati P. (1980): Catalase determination. Clin. Chem, 26: $227-231$.

8. Gaballah H, Gaber $A$ and Mohamed A (2017): Apigenin potentiates the antitumor activity of 5-FU on solid Ehrlich carcinoma: Crosstalk between apoptotic and JNK-mediated autophagic cell death platforms. Toxicology and Applied Pharmacology, 316: 27-35.

9. Gazzerro P, Proto MC, Gangemi G, Malfitano AM, Ciaglia $E$ and Pisanti S. (2012): Pharmacological actions of statins: a critical appraisal in the management of cancer. Pharmacol Rev., 64:102-46.

10. Ghaisas M M, Dandawate $P$ R, Zawar S A, Ahire Y S and Gandhi SP. (2010): Antioxidant, antinociceptiveand anti-inflammatory activities of atorvastatin and rosuvastatinin various experimental models. Inflammo Pharmacology, 18: 169-177.

11. Goard C A,Mather $R$ G,Vinepa IB, Clendening J W, Martirosyan A, Butros P C, Sharom F J and Penn L Z.(2010): Differential interactions between statins and Pglycoprotein: Implications for exploiting statins as anticancer agents, Int.J. Cancer, 127: 29362948.

12. Hindler K, Cleeland CS, Rivera $\mathbf{E}$ and Collard CD. (2006): The role of statins in cancer therapy. Oncologist, 11:306-315.

13. Hu GF and Riordan JF (1993): Angiogenin enhances actin acceleration of plasminogen activation. Biochem Biophys Res Commun., 197 (2): 682- 687.

14. Huang E, Johnson L, Eaton K, Hynes M, Carpentino $J$ and Higgins PR. (2010): Atorvastatin induces apoptosis in vitro and slows growth of tumor xenografts but not poly $\mathrm{p}$ formation in min mice. Dig. Dis. Sci., 55:3086-3094.

15. Jia L J, Xu H M, Ma D Y, Hu Q G, Huang $X$ F, Jiang $W \quad H$ and Hua $Z$ C. (2005): Enhanced therapeutic effect by combination of tumor-targeting Salmonella and endostatin in 


\section{OLA SAYED MOHAMED ALI $e t$ al.}

murine melanoma model. Cancer Biology \& therapy, 4(8):840-845.

16. Kabel a M, Abdel-Rahman M N, El-Sisi a E, Haleem M S, Ezzat NM and El Rashidy M A. (2013): Effect of atorvastatin and methotrexate on solid Ehrlich tumor. European Journal of Pharmacology, 713: 47-53.

17. Siegel R L, Miller K D and Jemal A. (2016): Cancer statistics. A cancer journal for clinicians, 66 (1): 7-30.

18. Koracevic D and Koracevic G. (2001): Determination of serum total antioxidant capacity. J. Clin. Pathol., 54: 356 - 361.

19. Li S, Yu W and Hu GF (2012): Angiogenin inhibits nuclear translocation of apoptosis inducing factor in a Bcl-2-dependent manner. Journal of Cellular Physiology, 227 (4): 16391644.

20. Oesterle A, Laufs U and Liao J K. (2017): Pleiotropic Effects of Statins on the Cardiovascular System. Circulation Research, 120 (1): 229-243.

21. Ohkawa H, Ohishi W and Yagi K A. (1979): Determination of Serum Lipid Peroxide., Biochem., 95:351-355.

22. Osman A e M, Ahmed M M, Khayyal M T and el Merzabani M M, (1993): "Hyperthermic potentiation of cisplatin cytotoxicity on solid Ehrlich carcinoma. Tumori, 79: 268-272.

23. Ozaslan M, Karagoz I D, Kilic I $H$ and Guldur M E. (2011): Ehrlich ascites carcinoma. Afr J Biotechnol., 10 (13): 23752378.

24. Patterson LT and Higginbotham ED. (1965): Mouse C - reactive protein and Endo-
toxin-Induced Resistance. J Bacteriology, 90: 1520-1524.

25. Pisanti S, Picardi P, Ciaglia E, D'Alessandro $A$ and Bifulco M (2014): Novel prospects of statins as therapeutic agents in cancer. Pharmacological research, 88: 84-98.

Salman T M, Omran G A, El-Naa M M and Doghish AS (2014): Protective effect of proanthocyanidins on nephrotoxicity induced by antitumor dose of cisplatin in ehrlich solid tumor-bearing mice. Arab J Lab Med., 40(2):953-965.

26. Torre L A, Islami F, Siegel R L, Ward E M and Jemal A. (2017): Global cancer in women: burden and trends. Cancer Epidemiology and Prevention Biomarkers, 26(4): 444-457.

27. Wali VB, Bachawal SV and Sylvester PW. (2009): Suppression in mevalonate synthesis mediates antitumor effects of combined statin and gamma to cotrienol treatment. Lipids, 44:925-934.

28. Xu H W, Xu L, Hao J.H, Qin C Y and Liu H. (2010): Expression of P-glycoprotein and multidrug resistance-associated protein is associated with multidrug resistance in gastriccancer. J. Int. Med. Res., (38):34-42.

29. Yang Z, Lee MJ, ZhaoY and Yang CS. (2012): Metabolism of tocotrienols in animals and synergistic inhibitory actions of to cotrienols with atorvastatinin cancer cells. Genes Nutr., 7:11-18. 


\section{دور الأتورفاستاتين فى تقليل الأكسدة الناجمة عن إستخدام

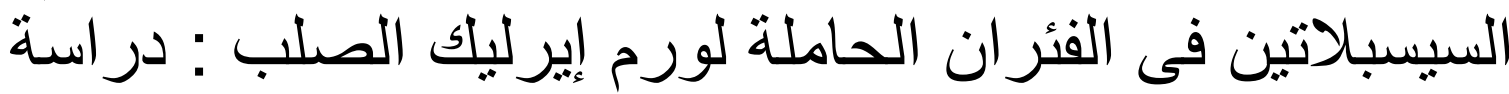 إستباقية مقارنة للحالات و الضو ابط الضر}

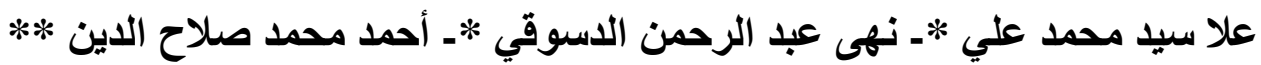

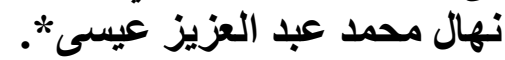

*قمم الكيمياء الحيويةـ كلية الصيدلة (بنات) - جامعة الأزهر

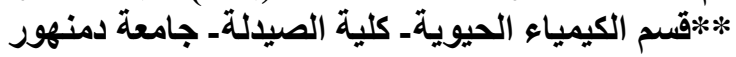

خلفية البحث : لوحظ وجود علاقة بين الكوليسترول وتحسن العديد من أنواع السرطان. ومع ذللك، فانن فعالية إضافة الأدوية المخفضة للاهون فى علاج السرطان غير و اضحة.

الهـف من البحث: وقد أجريت هذه الدر اسة لتقييم الدور المحتمل للأتورفاستاتين على الفئر ان الحاملة لورم إيرليك الصلب و المعالجة بالسيسبلاتين وتأثير ها على الالتهاب و الأكسدة.

مواد وطرق البحث: أجريت هذه الدر اسة على مجمو عة من الفئران عددها ستون فأر ا تم تقسيمها إلى خمس مجمو عـات : مجمو عـة سـليمة اسـتخدمت كمجموعـة ضـابطة ،مجمو عـة مصـابة دون عـلاج، مجمو عـة تعــالج بالسيسـبلاتين منفـردا، مجمو عـة تعـالج بالأتور فاسـتاتين منفـردا، مجمو عـة تعـالج بالأتورفاستاتين و السيسبلاتين معا.ومن ثم تم إز الة أنسجة الورم لفحوصـات الأنسجة وتم جمع عينات

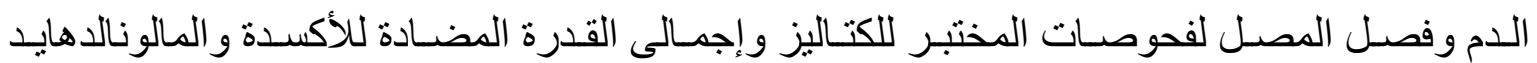
و الانجيوجينين وبروتين سى التفاعلى.

النتـائج:- كانـــ دلالات الأكسـدة هـي الأسـو أ في المجمو عـة المعالجـة بالسيسـبلاتين و الأفضـل في المجمو عة المعالجة بالأتورفاستاتين و السيسبلاتين معاً. كما كان هناك زيادة كبيرة في الكاتاليز في الدم وزيادة نسبية في إجمالى القدرة المضادة للأكسدة من المجموعـة المعالجة بالسيسبلاتين. و علاوة على ذللك، أظهر المالونديالدهيد إنخفاضـاً نسبياً فى مجموعة الجمع بين الأتورفاستاتين و السيسبلاتين عن المجمو عة المعالجة بالسيسبلاتين.

الإستتنتاج: أدى الاستخدام التنـائى لعـلاج الأتورفاستاتين / السيسبلاتين إلى زيـادة إنزيمـات مضـادات الأكسدة و إنخفاض الإجهاد التأكسدي الناجم عن سيسبلاتين ممـا يعكس التأثثر المضــاد للأكسدة مـن

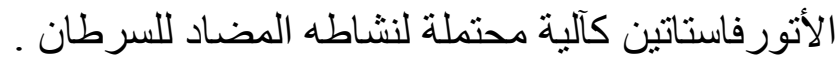

